\begin{tabular}{|c|c|}
\hline Title & How does managerial coaching affect individual learning? : The mediating roles of team and individual reflexivity \\
\hline Author(s) & Matsuo, Makoto \\
\hline Citation & $\begin{array}{l}\text { Personnel review, 47(1), 118-132 } \\
\text { https://doi.org/10.1108/PR-06-2016-0132 }\end{array}$ \\
\hline Issue Date & $2018-02$ \\
\hline Doc URL & http:/hdl.handle.net/2115/2100 \\
\hline Type & article (author version) \\
\hline Note(URL) & https:/www.emeral dinsight.com/doi full/10.1108/PR-06-2016-0132 \\
\hline File Information & SelfA rchiving_(PR_2018).pdf \\
\hline
\end{tabular}

Instructions for use 
Personnel Review, Vol 47, No. 1, 2018, pp. 118-132.

\title{
How does managerial coaching affect individual learning? The mediating roles of team and individual reflexivity
}

\author{
Makoto Matsuo \\ Graduate School of Economics and Business Administration, \\ Hokkaido University, Sapporo, Japan
}

\begin{abstract}
Purpose - The purpose of this paper is to examine the mediating role of team and individual reflexivity in linking managerial coaching with individual learning.

Design/methodology/approach - Data obtained from 506 individuals in 98 engineering teams in the automobile and electronic industries were used to investigate specific hypotheses.
\end{abstract}

Findings - The results indicated that managerial coaching directly influenced team learning and individual learning, team reflexivity acted as substantial mediator for the relationship between managerial coaching and team learning, as well as the relationship between managerial coaching and individual reflexivity and team reflexivity and individual reflexivity co-acted each other as mediators for the relationship between managerial coaching and individual learning.

Research limitations/implications - As the subjects of this study were engineering teams in which tasks are interdependent, there is a possibility that the task trait may have affected the results.

Practical implications - Managers should recognize the importance of collectively reflective activities in promoting both individual and team learning. Facilitating coaching skills are indispensable to enhance reflexivity within teams.

Originality/value - This study extends prior research by demonstrating the mediating role of team and individual reflexivity as mediators in linking managerial coaching to team and individual learning, which has never been investigated in previous studies.

Keywords Quantitative, Team reflexivity, Managerial coaching, Individual learning, Team learning, Individual reflexivity

Paper type Research paper 
The concept of coaching is becoming an important developmental approach to facilitating

employee learning and performance (Ellinger et al., 2003; Gray, 2006), given our increasingly fast-paced world (Kets de Vries, 2005). Heslin et al. (2006) argued that managers play important roles as coaches in providing one-on-one feedback that inspires improvements in their employees' work performance. Hierarchical coaching from line managers to their subordinates is the most well-known form of "managerial coaching," and the most widely researched (Beattie et al., 2014). There is an extensive academic literature on coaching, and its popularity in organizations has increased dramatically over the last decade (Segers and Inceoglu, 2012).

Although most of the research to date has assumed that managerial coaching directly affects individual learning outcomes (e.g. Agarwal et al., 2009; Ellinger et al., 2003; Elmadag et al., 2008), it is highly believed that managerial coaching promotes individual learning through team activities such as sharing knowledge and problem solving within teams. For example, Hackman and Wageman (2005) introduced the concept of "team coaching," emphasizing the role of team leaders in helping members make coordinated and task-appropriate use of their collective resources. Team coaching can be conceptualized as a set of leadership behaviors designed to enhance team ability and performance (Liu and Pirola-Merlo, 2009). McLean et al. (2005) also argued that managers as coaches should take a team approach instead of an individual approach to tasks. Previous research suggests that team processes may constitute an intermediate path between managerial coaching and individual learning. In other words, there may be two paths between managerial coaching and individual learning: a direct path, and an indirect path that involves team interactions. However, no previous studies have attempted to quantitatively investigate the two paths.

In investigating the mechanisms by which managerial coaching affects individual learning, the present research focused on the mediating role of reflexivity at the team and individual levels. Managers as coaches may facilitate collective reflexivity within a team by conducting "question-feedback interactions," which may enhance individual reflexivity and learning. That is, communication between team leaders and members is not limited to only one-on-one basis but also collective. This study extends prior research by demonstrating the mediating role of team and individual reflexivity in linking managerial coaching to individual learning, which has not been examined in previous studies.

In this paper, the literature on learning, reflexivity and managerial coaching is 
reviewed, and relevant hypotheses are proposed. Then the quantitative methods used to test these hypotheses are presented. Finally, the results are detailed and discussed from theoretical and practical perspectives.

\section{Theoretical background}

\section{Learning and reflexivity}

Learning is generally referred to as the process of acquiring knowledge and skills (Antonacopoulou, 2006). More specifically, Marsick and Watkins (1990) conceptualized learning as the way in which individuals or groups acquire, interpret, reorganize, change or assimilate clusters of related information, skills and feelings ( p. 4). However, there are two different concepts in the definition of learning: "learning processes" and "learning outcomes" (Edmondson, 1999). With respect to learning processes, Edmondson (1999) conceptualized "team learning behavior" as an ongoing process of reflection and action, characterized by asking questions, seeking feedback, experimenting, reflecting on results and discussing errors or unexpected outcomes. This should be distinguished from "learning outcomes" such as adaptation to change, greater understanding or improved performance in teams.

The present research focused on team reflexivity, which can be described as a team learning process. Therefore, individual and team learning were conceptualized as outcomes rather than processes to avoid conceptual overlap among variables. Following previous studies of workplace learning (Clarke, 2005; Fenwick, 2008; Zellmer-Bruhn and Gibson, 2006), "team learning" was defined as the extent to which a team introduces and improves work processes, develops team members and enhances task performance. Consistent with this definition, individual learning refers to the extent to which an individual acquires knowledge and skills to perform tasks, improve work processes and enhance performance.

This paper focuses on the role of reflexivity at the individual and team levels. According to Kolb’s (1984) experiential learning model, individuals acquire knowledge and skills through reflection on personal experience. His model suggests that reflective activities are essential to convert tacit experience into explicit knowledge (DeFillippi, 2001). In the initial and continuing development of professionals, reflection has been regarded as strategically important (Boud et al., 2006; Chivers, 2003). van Woerkom and Croon (2008) also suggested that reflection is widely recognized as crucial elements in learning process in organizations. In the present study, individual reflexivity was defined as the extent to which a subject periodically reviews his or her work objectives and methods. This definition suggests that "reflexivity" as a disposition or tendency 
should be distinguished from "reflection" as an activity or practice. Kolb's (1984) experiential learning theory predicts that individuals can learn well from work experiences when they periodically reflect on their work objectives or processes. Specifically, individuals extract lessons from their personal experience through reflective observations (Kolb, 1984). Thus, the following hypothesis is proposed:

H1. Individual reflexivity is positively related to individual learning.

Reflexivity has been conceptualized not only at the individual level but also at the team level. West (1996) defined team reflexivity as the extent to which group members overtly reflect upon the group's objectives, strategies and processes, and adapt them to current or anticipated endogenous or environmental circumstances ( p. 559). This concept is important because a team's environment is constantly changing, and constant reflection and contemplation are therefore necessary to select the best action for the current environment (Hoegl and Parboteeah, 2006). Vashdi et al. (2007) argued that a variety of HR systems should be restructured to enable teams to effectively engage in and benefit from team reflexivity. Several empirical studies have reported that team reflexivity is positively associated with new product success (Dayan and Basarir, 2010; Lee, 2008), team effectiveness (Hoegl and Parboteeah, 2006), team innovation (Schippers et al., 2015; Somech, 2006) and team functioning (van Ginkel et al., 2009). Regarding the function of team reflexivity, Schippers et al. (2015) suggested that members can generate new ideas for improvement and work processes and share the ideas through reflecting on team's objectives, strategies and processes. Because team reflexivity enables team members to review goals and work processes to adapt to environmental change, it should promote team learning. Thus, the following hypothesis is proposed:

H2a. Team reflexivity is positively related to team learning.

Collective reflection in the team may inspire individual members to reflect on their views, attitude and behaviors. For example, Jordan (2010) found that individual reflection was fostered by practices such as explicit reference of experienced colleagues to multiple alternative procedures, diverse perspective and the necessity of asking. These features are often included in team reflection (West, 1996). Similarly, Hirst et al. (2009) stated that team learning behaviors, including collective reflection, encourage social learning processes in which team members observe others engaging in learning activities. Based on these arguments, team reflexivity may promote individual reflexivity by providing members with alternative procedures, diverse perspectives and questions on work processes. Thus, the following hypothesis is proposed:

$H 2 b$. Team reflexivity is positively related to individual reflexivity. 


\section{Managerial coaching}

Team reflexivity may be influenced by coaching because the key capabilities for coaching include listening and questioning skills (Hooijberg and Lane, 2009), which are necessary for promoting reflection. Generally, coaching is an activity that helps people to perform their tasks (Hackman and Wageman, 2005). There are two main streams of research in the coaching literature: executive coaching and managerial (or employee and developmental) coaching (Agarwal et al., 2009). The former is a process that involves a series of one-on-one interactions between an executive and an external coach for the purpose of improving the executive's work effectiveness (Bono et al., 2009; Feldman and Lankau, 2005; Kilburg, 1996), while the latter occurs in the workplace as part of the day-to-day relationship between employees and supervisors (Elmadag et al., 2008). Managerial coaching is frequently described in different ways, such as employee coaching (Heslin et al., 2006), developmental coaching (Agarwal et al., 2009) and supervisory coaching (Baron and Morin, 2009). This paper uses only the encompassing “managerial coaching” term.

This study focused on managerial coaching because it is a skill that most managers need to develop as an integral part of their everyday practice (Hamlin et al., 2006). Despite the fact that coaching is viewed by practitioners as a primary way to develop and motivate employees, empirical research on the effectiveness of the coaching process is lacking (Feldman and Lankau, 2005; Theeboom et al., 2014). Grant et al. (2010) stated that coaching practices are largely disconnected from academic research, and, until recently, few studies on coaching practices have been published in academic journals.

Ellinger et al. (2003) conceptualized coaching as a form of facilitative learning to encourage growth and development. Coaching behaviors are crucial not only for executives and senior managers but also for first-line supervisors; a growing trend in workplace coaching is now focused on line managers who coach their subordinates (Butler et al., 2008; Ellinger et al., 2011). Managers who are effective at developing employees have incorporated coaching skills into their management style (Orth et al., 1997; Stoker, 2008).

As suggested above, empirical research on this topic is still in the early developmental stage ( Ellinger et al., 2011). Beattie (2006) stated that much of the literature on the developmental roles that managers play, such as the roles of mentor and coach, is prescriptive and rhetorical, but there have been a number of empirical studies 
on what managers do as learning facilitators.

Using the critical incident technique, Ellinger and Bostrom (1999) reported that managerial coaching behavior as a facilitator of learning can be divided into two types: empowering and facilitating. "Empowering behavior" refers to giving more power and authority to employees by encouraging them to assume more personal responsibility and accountability for their actions and decisions. "Facilitating behavior" promotes new levels of understanding and new perspectives, and offers guidance and support to employees to help foster learning and development. Similarly, Heslin et al. (2006) developed the three-factor measure of managerial coaching that includes facilitation (helping employees to analyze and explore ways to solve problems and enhance their performance), guidance (communication of clear performance expectations and constructive feedback regarding performance outcomes, as well as how to improve) and inspiration (challenging employees to realize and develop their potential). Hui et al. (2013) also distinguished "facilitation coaching" (helping employees to explore and evaluate the task, and self-developing the correct responses for improving performance) from "guidance coaching” (delivering clear expectations and directive feedback about how to improve). These studies indicate that managerial coaching facilitates reflection by subordinates, provides feedback to improve their performance and motivates them to accept a challenge.

Most previous empirical studies have focused on the influence of managerial coaching on a subordinate's attitude, behavior, learning and performance at the individual level. For example, managerial coaching behavior is positively associated with employee job satisfaction (Ellinger et al., 2003; Kim et al., 2013), commitment to service quality (Elmadag et al., 2008), role clarity (Kim et al., 2013), sales skills (Good, 1993), training effectiveness and efficiency (Passmore and Rehman, 2012) and performance (Agarwal et al., 2009; Liu and Batt, 2010). By performing a meta-analysis, Theeboom et al. (2014) showed that coaching has significant positive effects on performance, skills, well-being, coping, work attitude and goal-directed self-regulation. In addition, Sonesh et al. (2015) found that coaching has stronger effects on the relationship between mentor and mentee than it does on the attainment of goals.

However, only limited studies have investigated the effects of managerial coaching on team-level factors. For example, Wageman (2001) found that leaders' hands-on coaching influenced team self-management, the quality of member relationships and member satisfaction. Using survey data from work teams in a public safety organization, Rousseau et al. (2013) showed that team coaching has a positive influence on team goal commitment and support for innovation. Hagen and Aguilar 
(2012) also conducted a survey of leaders and members of 210 Six Sigma teams in manufacturing and service organizations, and found that coaching expertise had a positive impact on team learning outcomes.

These results suggest that managerial coaching enhances both individual learning and team learning by giving feedback to improve their performances and motivating them to accept challenges (Ellinger and Bostrom, 1999; Heslin et al., 2006). Therefore, the following hypotheses are proposed:

H3a. Managerial coaching is positively related to team learning.

$H 3 b$. Managerial coaching is positively related to individual learning.

Managerial coaching will also promote team reflexivity, because the manager's facilitative support using "listening” and “questioning” skills (Hooijberg and Lane, 2009) may help team members to reflect on their work processes. Several authors have found that team reflexivity was affected by facilitative leadership (Hirst et al., 2004) and transformative leadership (Schippers et al., 2008). These studies indicate that leaders facilitate team reflexivity by creating an atmosphere in which members can express their ideas and opinions openly, and by promoting shared visions within the team. Accordingly, DeRue et al. (2012) argued that a facilitator plays a very important role in promoting systematic reflection after events. Among the three dimensions of managerial coaching proposed by Heslin et al. (2006), “facilitation," or helping employees to explore ways to solve problems, will promote reflective activities at both the team and individual levels. This function of coaching is not intended to provide solutions to problems, but to encourage and enlighten the team and members to examine the problems and to generate the solutions on their own. Thus, the following hypotheses are proposed:

H3c. Managerial coaching is positively related to team reflexivity.

$H 3 d$. Managerial coaching is positively related to individual reflexivity.

\section{Mediation hypotheses}

Figure 1 schematically shows a research model that summarizes the aforementioned hypotheses. As shown in this model, three mediation hypotheses can be proposed. Figure 1 shows that team reflexivity mediate the effect of managerial coaching on team learning, individual reflexivity and subsequently individual learning. Based on H2a, $\mathrm{H} 2 \mathrm{~b}$, and H3c, the following mediation hypotheses were proposed:

H4a. Team reflexivity mediates the relationship between managerial coaching and team learning.

$H 4 b$. Team reflexivity mediates the relationship between managerial coaching 
and individual reflexivity.

Figure 1 also suggests that individual reflexivity mediates the effect of team reflexivity on individual learning. Based on the $\mathrm{H} 1$ and $\mathrm{H} 2 \mathrm{~b}$, the following hypothesis was proposed:

H4c. Individual reflexivity mediates the relationship between team reflexivity and individual learning.

Because the model involves both team-level factors (managerial coaching, team reflexivity and team learning) and individual-level factors (individual reflexivity and individual learning), a multi-level study that simultaneously examines factors at both levels is warranted. Having introduced the research framework, an empirical test of the model is discussed in the following section.

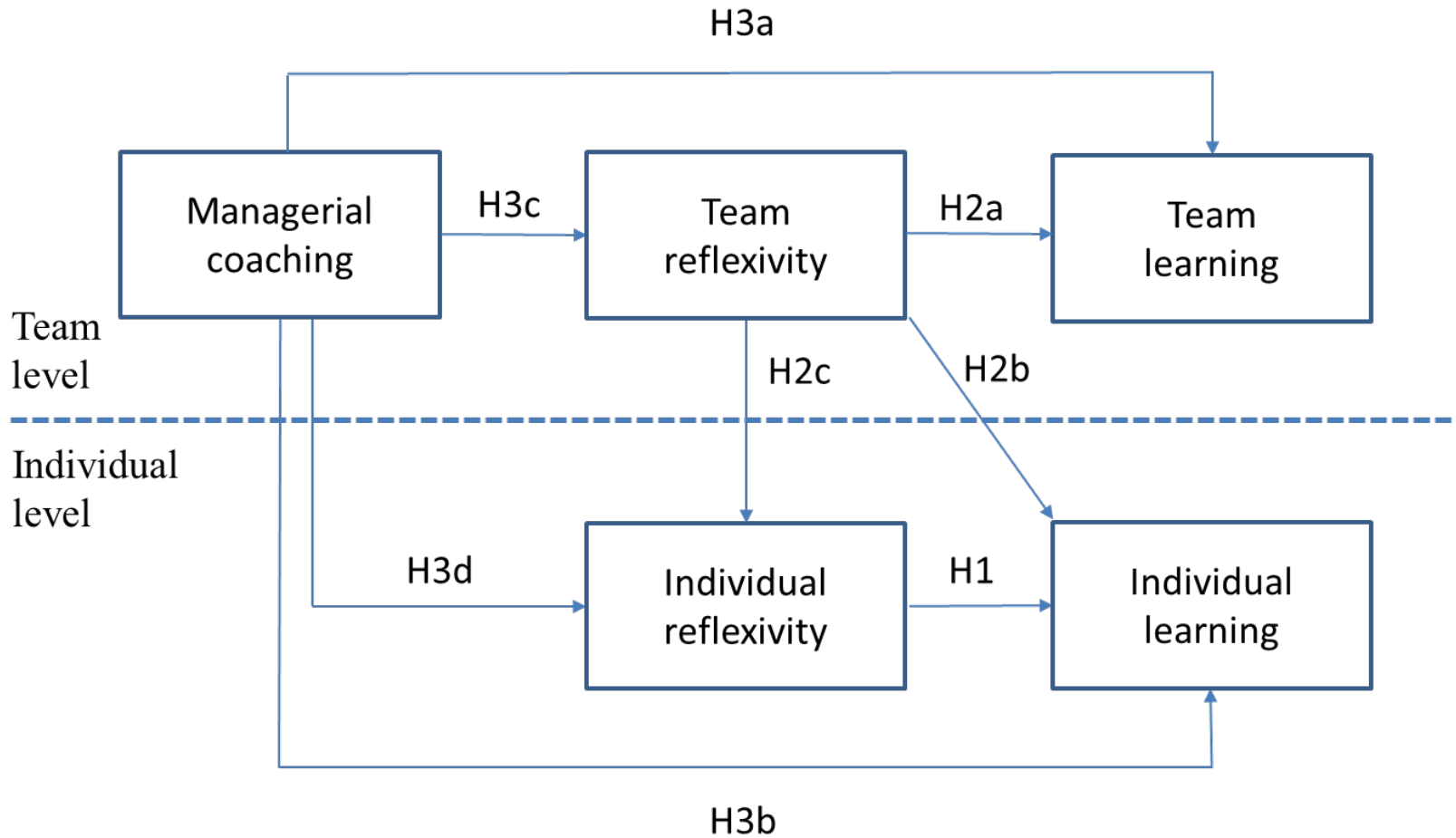

Figure 1. Research model

\section{Methodology}

Participants and procedure

The research setting consisted of the engineering departments of two large Japanese 
manufacturers in the automotive and electronics industries. Engineers at both firms engaged in product development. These sites had the advantage of offering team-based workplaces in which tasks were interdependent. In this study, questionnaires were distributed to 552 employees (non-managerial) belonging to 98 teams (461 employees in 70 teams at the automaker and 91 employees in 28 teams at the electronics maker) using a web-based survey system operated by the individual firms. Participants were asked to respond to questionnaires on the coaching provided by their team leaders ( junior managers), team reflexivity, team learning, individual reflexivity and individual learning. The questionnaires required the participant to describe the behavior of their team superiors without using the term coaching. Neither firm had provided team leaders with training on coaching techniques before the surveys were conducted. Team leaders were excluded from the survey because this study examined coaching behaviors from the team members' perspective. In total, 506 questionnaires (98 teams) were considered usable after removing four with inappropriate answers. The survey response rate was 91.7 percent. The main reason for the high response rate may be that the two firms have traditional Japanese management styles and employees generally follow directions from their superiors. Since the human resource departments of both firms promoted their importance, employees may have felt some responsibility to complete the survey. Regarding the discrepancies in response rate of mail survey among countries, Harzing (1997) reported that there have been consistently high response rates in Japan. The average team size (the number of respondents) was 5.16 (standard deviation (SD) = 3.22). The sample was 96.4 percent male, a proportion that is typical of engineering departments in Japanese firms. The average job tenure was 10.09 years (SD = 5.18). The distribution of participants' ages was as follows: 29 years and younger (36.6 percent), 30-39 (56.2 percent) and 40 years and older (7.2 percent).

\section{Measures}

The measures used in this study were adapted from previously published studies, except for those related to individual and team learning, which were developed based on prior research. Back-translation was conducted to minimize discrepancies between the original and translated questionnaires. First, the author translated the English version of the questionnaire into Japanese. This translated Japanese version was then back-translated into English by a bilingual language professional. In situations in which the back-translation was not equivalent to the original version, the translated Japanese items were revised.

Managerial coaching. Managerial coaching was measured using a ten-question 
scale from Heslin et al. (2006). Following their study, team members' ratings of their leader's coaching behavior were averaged into a single mean score for each participant. Examples of the questions included: "Provides guidance regarding performance expectations?," "Offers useful suggestions regarding how you can improve your performance?," "Encourages you to explore and try out new alternatives?” and "Supports you in taking on new challenges?” (1 = strongly disagree, 5 = strongly agree), $\alpha=0.96$.

Team reflexivity. Team reflexivity was measured using a six-item scale selected from West (2000). The items were: "We regularly discuss whether the team is working effectively together;" "The methods used by the team to get the job done are often discussed;" "The team often reviews its objectives;" "In this team we modify our objectives in light of changing circumstances;" "How well we communicate information is often discussed" and "This team often reviews its approach to getting the job done” ( 1 = strongly disagree, $5=$ strongly agree $), \alpha=0.91$. The average scores of the items were used in the analyses.

Team learning. Team learning was measured using a four-item scale based on studies of workplace learning (Fenwick, 2008; Zellmer-Bruhn and Gibson, 2006; Clarke, 2005). The items were: "Task performance capabilities of team members are improving;" "New work processes and systems are being introduced in our team;" "Work processes and systems are being improved in our team" and "Task performance capabilities of the team are highly valued in the organization” 1 = strongly disagree, $5=$ strongly agree), $\alpha$ $=0.78$. The average scores of the items were used in the analyses.

Individual reflexivity. Individual reflexivity was measured using a five-item scale selected from West (2000). The items are: "I often review my work objectives;" "I often reflect upon whether I am working effectively;" "I often review the methods I use to get the job done;" "I modify my work objectives in the light of changing circumstances at work" and "I often review my approach to getting the job done." Each item measured reflection on a five-point Likert scale $(1=$ strongly disagree, $5=$ strongly agree), $\alpha=0.87$. The average scores of the items were used in the analyses.

Individual learning. Individual learning was measured with a three-item scale developed for the present research from studies of workplace learning (Fenwick, 2008; Zellmer-Bruhn and Gibson, 2006; Clarke, 2005). The items were "My abilities to perform tasks are improving," "I am improving work process efficiency in relation to my tasks" and "My performance is highly valued in the organization" ( 1 = strongly disagree, $5=$ strongly agree), $\alpha=0.77$. The average scores of the items were used in the analyses. 


\section{Validation of measures}

The intraclass correlation coefficient $\mathrm{r}_{\text {wg(j) }}$ was calculated to assess within-team agreement (James et al., 1984). A value of 0.70 or above suggests good within-group inter-rater agreement (George, 1990). The $\mathrm{r}_{\mathrm{wg}(\mathrm{j})}$ averaged 0.94 for managerial coaching, 0.93 for team reflexivity and 0.90 for team learning. Between-unit variance was significant for managerial coaching $(F=2.03, \mathrm{p}<0.001)$, team reflexivity $(F=1.36, \mathrm{p}$ $<0.05)$ and team learning $(F=2.20, \mathrm{p}<0.001)$. The scores suggest that team members had relatively uniform perceptions of the variables.

To evaluate whether the data met statistical criteria for aggregation, the interclass correlation coefficients (ICC1 and ICC2), which provide indications of the proportion of group-level variance (van Mierlo et al., 2009), were calculated. The ICC1 values were 0.17 for managerial coaching, 0.07 for team reflexivity and 0.17 for team learning. The ICC2 values were 0.51 for managerial coaching, 0.27 for team reflexivity and 0.51 for team learning. The ICC1 and ICC2 values were beyond the cut-off scores of 0.12 for ICC1 (James, 1982) and 0.50 for ICC2 (LeBreton and Senter, 2008), except for team reflexivity. Regarding this issue, Bal et al. (2012) note that many studies have reported low ICC scores. Because all of the $r_{w g(j)}$ values were $>0.70$ and all between-unit variances were significant, the data for these three scales were aggregated to the unit level by taking the mean within each unit.

To evaluate the convergent validity of the model constructs, a confirmatory factor analysis (CFA) was conducted with five latent learning constructs (on managerial coaching, team reflexivity, team learning, individual reflexivity and individual learning) and a total of 29 items. CFA is a frequently used tool to examine convergent and discriminate validity (Shaffer et al., 2016). The results showed that all items loaded significantly on the respective constructs; the goodness-of-fit statistics for the model were as follows: $\chi^{2}=1,149.68(\mathrm{df}=367, \mathrm{p}<0.001$ ), comparative fit index $=0.92$, Tucker-Lewis index $=0.91$, root mean square error of approximation $=0.065$ and root mean square residual $=0.028$. The fit indices of the model were acceptable.

Table I. Means, standard deviations and individual-level correlations of the variables 


\begin{tabular}{|c|c|c|c|c|c|c|c|c|c|}
\hline & Level & $\mathrm{M}$ & SD & 1 & 2 & 3 & 4 & 5 & 6 \\
\hline 1 Team size & 2 & 7.99 & 3.60 & & & & & & \\
\hline 2 Organization (1= auto A, $2=$ electronic) & 2 & 1.17 & .37 & -.46 & & & & & \\
\hline 3 Managerial coaching & 2 & 3.48 & .76 & -.01 & .06 & $(.96)$ & & & \\
\hline 4 Team reflexivity & 2 & 3.17 & .70 & $.10^{*}$ & -.06 & $.60 * * *$ & $(.91)$ & & \\
\hline 5 Team learning & 2 & 3.42 & .61 & $.12^{* *}$ & -.05 & $.55^{* * *}$ & $.65^{* * *}$ & $(.78)$ & \\
\hline 6 Individual reflexivity & 1 & 3.41 & .57 & .08 & -.08 & $.30^{* * *}$ & $.49^{* * *}$ & $.39^{* * * *}$ & $(.87)$ \\
\hline 7 Individual learning & 1 & 3.45 & .58 & .04 & -.05 & $.26^{* * *}$ & $.38^{* * *}$ & $.40^{* * *}$ & $.68^{* * *}(.77)$ \\
\hline
\end{tabular}

Convergent validities of the factors were also estimated by the average variance extracted (AVE). The AVE estimate is the average amount of variance that a latent construct can explain in the observed variables to which it is theoretically related (Farrell, 2010). The AVE for managerial coaching, team reflexivity, team learning, individual reflexivity and individual learning were $0.69,0.62,0.48,0.52$ and 0.54 , respectively. Considering the recommended limit of 0.50 , the scores are acceptable.

\section{Results}

The means, SDs and inter-correlations of the variables are presented in Table I. All variables were indexed at the individual level. This study provides data at the "individual level" (individual reflexivity and individual learning), as well as at the higher "team level” (managerial coaching, team reflexivity and team learning). In the analysis of the model, the effect of team size is controlled by incorporating it as an independent variable. All variables examined in the analyses were grand-mean centered.

Multi-level analyses were conducted to test the hypotheses (Table II and Figure 2). $H 1$ states that individual reflexivity positively influences individual learning. The results show that individual reflexivity was significantly related to individual learning (0.67, $\mathrm{p}<0.001$ ), offering support for $H 1$. $H 2 a$ and $H 2 b$ state that team reflexivity positively influences team learning $(H 2 a)$ and individual reflexivity $(H 2 b)$. The results indicate that team reflexivity was significantly related to team learning $(0.48, \mathrm{p}<0.001)$ 
Table II. Results of the multi-level analysis $(\mathrm{n}=506$; $\mathrm{k}=98)$

\begin{tabular}{|c|c|c|c|c|}
\hline Variable & $\begin{array}{l}\text { Team } \\
\text { reflexity }\end{array}$ & $\begin{array}{l}\text { Team } \\
\text { learning }\end{array}$ & $\begin{array}{l}\text { Individual } \\
\text { reflexivity }\end{array}$ & $\begin{array}{c}\text { Individual } \\
\text { learning }\end{array}$ \\
\hline \multicolumn{5}{|l|}{ (Control variables) } \\
\hline Team size & $.01(.01)^{* * *}$ & $.01(.01)^{* * *}$ & $.01(.01)$ & $-.01(.01)$ \\
\hline $\begin{array}{l}\text { Organization } \\
\text { (1= auto A, } 2=\text { electronic) }\end{array}$ & $-.10(.03)^{* *}$ & $-.01(.02)$ & $-.07(.07)$ & $-.02(.05)$ \\
\hline Managerial coaching & $.49(.02)^{* * *}$ & $.29(.02)^{* * *}$ & $-.04(.07)$ & $.14(.05)^{*}$ \\
\hline Team reflexivity & & $.48(.03)^{* * *}$ & $.45(.09)^{* * *}$ & $.01(.07)$ \\
\hline Individual reflexivity & & & & $.67(.03)^{* * *}$ \\
\hline
\end{tabular}

and individual reflexivity $(0.45, \mathrm{p}<0.001)$. Therefore, $H 2 a$ and $H 2 b$ were supported. The results also show that managerial coaching was significantly related to team learning $(0.29, \mathrm{p}<0.001)$, individual learning $(0.14, \mathrm{p}<0.05)$ and team reflexivity (0.49, $\mathrm{p}<0.001)$, but not significantly related to individual reflexivity $(-0.04, \mathrm{~ns})$, which supports $H 3 a-H 3 c$, but not $H 3 d$.

\section{Discussion}

Previous research on coaching has mainly focused on the "one-on-one" relationship between the coach and the coachee (Heslin et al., 2006), while fewer studies have reported on the effect of a team leader's coaching on team effectiveness (Hagen and Aguilar, 2012; Wageman, 2001). The present study contributes by investigating not only the direct influence of managerial coaching to team and individual learning but also the mediating effects of team and individual reflexivity toward team and individual learning. The results suggest that team and individual reflexivity may be formed as a set of multiple and co-existing mediators that link managerial coaching with team and individual learning. 
$.29^{* * *}$

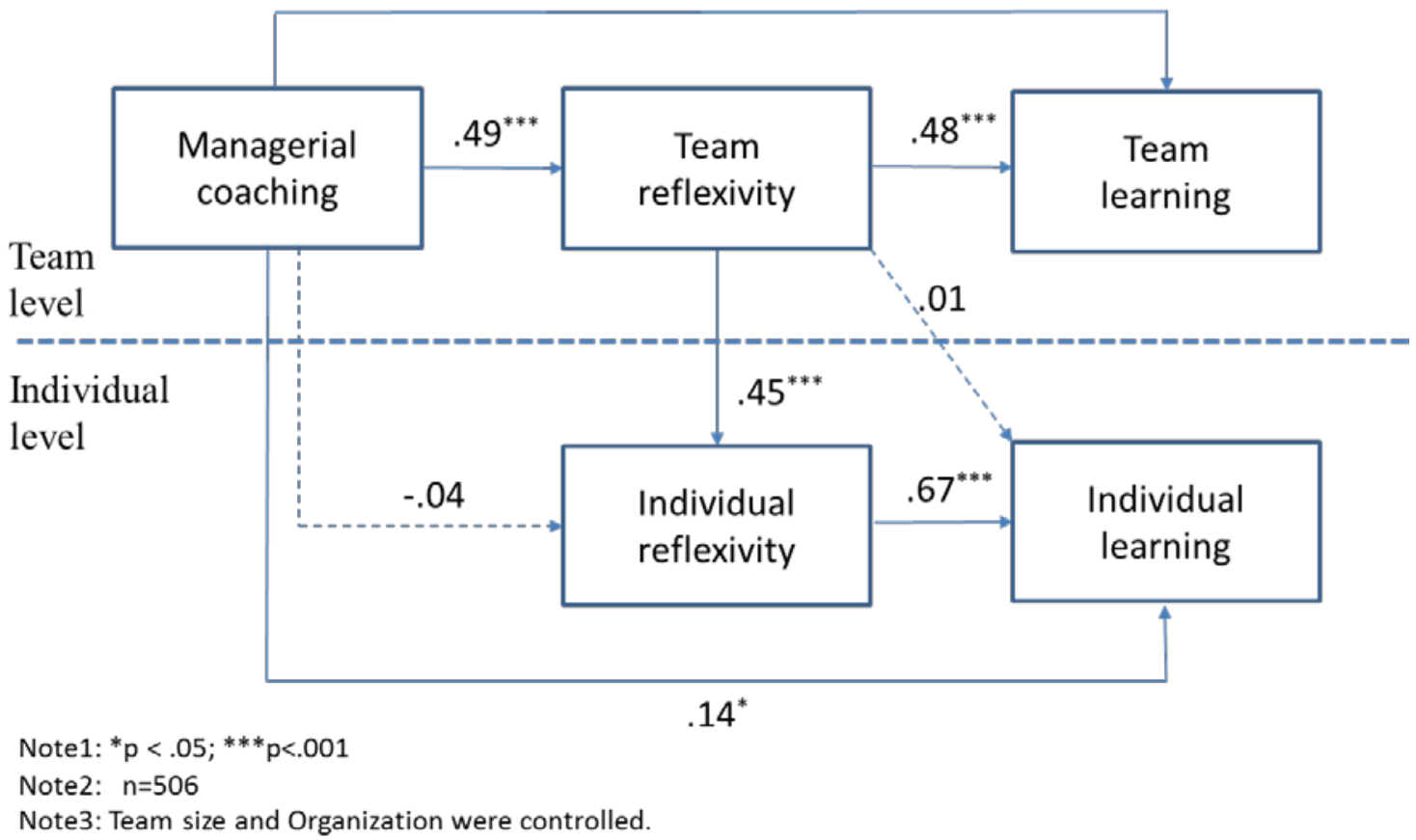

Figure 2. Summary of the multi-level analysis.

\section{Theoretical implications}

The findings of this study extend previous research on managerial coaching and team learning in four important ways. First, the present research identified the multiple and co-existing mediators' role of team and individual reflexivity between managerial coaching and team and individual learning. Although past studies have examined the influence of managerial coaching on both individual performance (e.g. Agarwal et al., 2009; Ellinger et al., 2003; Elmadag et al., 2008) and team effectiveness (e.g. Wageman, 2001; Hagen and Aguilar, 2012), few research has examined the functional effect of team and individual reflexivity as a single and a set of multiple mediators. This effect may relate to the nature of teams in which members' tasks are interdependent (De Dreu, 2007). Marks et al. (2001) suggested that team processes are the means by which members work interdependently to utilize various resources, such as expertise, equipment and monetary instruments, to yield meaningful outcomes. Team members can thereby acquire new knowledge and improve their work processes through collective reflection on their team's objectives, strategies and processes.

Second, the findings demonstrate that team members learn new skills and 
knowledge though individual reflection, which is inspired by collective reflection within a team. It can thus be inferred that team reflexivity encourages the social learning of individual members, as suggested by Hirst et al. (2009). Specifically, by engaging in collective reflection within the team, members may learn to reflect on their work processes and understand their performance-improving value. The results also indicate that team coaching (Wageman, 2001; Hagen and Aguilar, 2012) is closely linked with one-on-one coaching through reflexivity. Therefore, promoting reflection both at the individual and team level may be an essential skill in managerial coaching.

Third, this study identified the role of managerial coaching as an antecedent of team reflexivity. Previous research has reported that facilitative or transformational leadership is positively related to team reflexivity (Hirst et al., 2004; Schippers et al., 2008), yet few studies have investigated the effects of managerial coaching on team reflexivity. Among the three components of coaching behaviors proposed by Heslin et al. (2006), facilitating behaviors (i.e. helping employees to explore ways to solve problems and enhance their performance) may promote reflexivity within a team. Furthermore, as Ellinger and Bostrom (1999) suggested, good coaches empower team members by holding back the final answers and offering questions to encourage members to think through issues for themselves. Regarding empowering leadership, Chen et al. (2011) reported its influence on the psychological empowerment of team members. The present study indicated that the role of managerial coaching in enhancing reflexivity is not limited to the individual level but is also relevant at the team level.

Finally, this study found that managerial coaching has direct impacts on both team and individual learning. This finding is consistent with previous research on managerial coaching (e.g. Agarwal et al., 2009; Liu and Batt, 2010; Ellinger et al., 2003; Kim et al., 2013) and team coaching (e.g. Wageman, 2001; Hagen and Aguilar, 2012). These impacts may be attributable to the functions of coaching in providing guidance, advice on how to improve, and inspiration for employees to realize their potentials (Heslin et al., 2006). Managerial coaching can enhance individual and team learning and it can, therefore, be described as facilitative leadership (Ellinger et al., 1999).

\section{Practical implications}

This research has some practical implications for promoting learning within teams and organizations. First, competent team leaders should recognize the importance of collectively reflective activities, such as team meetings, for reviewing objectives and work processes in promoting both individual and team learning. To enhance reflexivity within teams, facilitating coaching skills is indispensable because they encourage team 
members to reflect on and discuss their experiences. Thus, good team leaders are able to use such coaching skills in one-on-one meetings as well as in collective meetings. It is vital for HRM managers to understand that individual team members can learn through reflective dialogue and discussions in collective meetings.

Second, HRM managers should recognize managerial coaching as a necessary management skill for team leaders. Although managerial coaching has been considered a managerial skill for fostering limited one-on-one relationships with subordinates, managers need to reconsider its role in learning leadership. As Hamlin et al. (2006) suggested, managerial coaching is at the heart of managerial effectiveness. Creating a coaching culture throughout the organization may enhance learning at all levels.

Third, it is important to develop HRM systems that strengthen managers' facilitation skills, because those skills are crucial for promoting collective reflection within teams. Because facilitation skills for one-on-one interviews may differ from those for collective meetings, training programs for developing these skills in the context of collective meetings must be provided. Additionally, an assessment center or survey feedback system may be effective to evaluate and improve a manager's facilitation skills within the managerial coaching context.

\section{Limitations and future research}

The limitations of this study should be acknowledged. First, there is a possibility that the task trait may have affected the results because the subjects of this study were engineering teams in which tasks are interdependent. If the subjects had been members of teams in which tasks were independent, it is possible that the mediating effect of team reflexivity on learning would have been smaller. Future research should examine the moderating effect of task dependency on the coaching-learning relationship using data obtained from diverse teams.

Second, as this study used data from employees in Japanese manufacturing firms, the group-oriented national culture may have affected the results. Both firms analyzed in this study employ traditional Japanese management styles in which employees tend to obey directions from superiors. Therefore, the findings in this study may not be applicable to Western or other Asian countries. There is a need for research in other countries to verify the model.

Finally, the scales of individual and team learning were developed for this research. Although the scales were designed based on workplace learning literature (Fenwick, 2008; Zellmer-Bruhn and Gibson, 2006; Clarke, 2005), the validity and reliability of the scales should be examined in future research. 


\section{References}

Agarwal, R., Angst, C.M. and Magni, M. (2009), “The performance effects of coaching: a multilevel analysis using hierarchical linear modeling”, International Journal of Human Resource Management, Vol. 20 No. 10, pp. 2110-2134.

Antonacopoulou, E.P. (2006), “The relationship between individual and organizational learning: new evidence from managerial learning practices”, Management Learning, Vol. 37 No. 4, pp. 455-473.

Bal, P.M., De Jong, S.B., Jansen, P.G.W. and Bakker, A.B. (2012), "Motivating employees to work beyond retirement: a multi-level study of the role of I-deals and unit climate”, Journal of Management Studies, Vol. 49 No. 2, pp. 306-331.

Baron, L and Morin, L. (2009), “The coach-coachee relationship in executive coaching: a field study”, Human Resource Development Quarterly, Vol. 20 No. 1, pp. 85-106.

Beattie, R.S. (2006), "Line managers and workplace learning: learning from the voluntary sector”, Human Resource Management International, Vol. 9 No. 1, pp. 99-119.

Beattie, R.S., Kim, S., Hagen, M.S., Egan, T.M., Ellinger, A.D. and Hamlin, R.G. (2014), "Managerial coaching: a review of the empirical literature and development of a model to guide future practice”, Advances in Developing Human Resources, Vol. 16 No. 2, pp. 184-201.

Bono, J.E., Purvanova, R.K., Towler, A. and Peterson, D.B. (2009), "A survey of executive coaching practices”, Personnel Psychology, Vol. 62 No. 2, pp. 361-404.

Boud, D., Cressey, P. and Docherty, P. (2006), "Setting the scene for productive reflection”, in Boud, D., Cressery, P. and Docherty, P. (Eds), Productive Reflection at Work: Learning for Changing Organizations, Routledge, Oxon, pp. 3-10.

Butler, D., Johnson, L. and Forbes, B. (2008), “An examination of a skills-based leadership coaching course in an MBA program”, Journal of Education for Business, Vol. 83 No. 4, pp. 227-232.

Chen, G., Sharma, P.N., Edinger, S.K., Shapiro, D.L. and Farh, J. (2011), “Motivating and demotivating forces in teams: cross-level influences of empowering leadership and relationship conflict”, Journal of Applied Psychology, Vol. 96 No. 3, pp. 541-557.

Chivers, G. (2003), "Utilising reflective practice interviews in professional 
development”, Journal of European Industrial Training, Vol. 27 No. 1, pp. 5-15.

Clarke, N. (2005), "Workplace learning environment and its relationship with learning outcomes in healthcare organizations”, Human Resource Development International, Vol. 8 No. 2, pp. 185-205.

Dayan, M. and Basarir, A. (2010), "Antecedents and consequences of team reflexivity in new product development projects”, Journal of Business \& Industrial Marketing, Vol. 25 No. 1, pp. 18-29.

De Dreu, C.K. (2007), “Cooperative outcome interdependence, task reflexivity, and team effectiveness: a motivated information processing perspective”, Journal of Applied Psychology, Vol. 92 No. 3, pp. 628-638.

DeFillippi, R.J. (2001), "Introduction: project-based learning, reflective practices and learning”, Management Learning, Vol. 32 No. 1, pp. 5-10.

DeRue, D.S., Nahrgang, J.D., Hollenbeck, J.R. and Workman, K. (2012), “A quasi-experimental study of after-event reviews and leadership development”, Journal of Applied Psychology, Vol. 97 No. 5, pp. 997-1015.

Edmondson, A.C. (1999), "Psychological safety and learning behavior in work teams", Administrative Science Quarterly, Vol. 44 No. 2, pp. 350-383.

Ellinger, A.D. and Bostrom, R.P. (1999), "Managerial coaching behaviors in learning organizations”, Journal of Management Development, Vol. 18 No. 9, pp. 752-771.

Elmadag, A.B., Ellinger, A.E. and Franke, G.R. (2008), “Antecedents and consequences of frontline commitment to service quality”, Journal of Marketing Theory and Practice, Vol. 16 No. 2, pp. 95-110.

Ellinger, A.D., Ellinger, A.E. and Keller, S.B. (2003), “Supervisory coaching behavior, employee satisfaction, and warehouse employee performance: a dyadic perspective in the distribution industry", Human Resource Development Quarterly, Vol. 14 No. 4, pp. 435-458.

Ellinger, A.D., Watkins, K.E. and Bostrom, R.P. (1999), "Managers as facilitators of learning in learning organizations”, Human Resource Development Quarterly, Vol. 10 No. 2, pp. 105-125.

Ellinger, A.D., Ellinger, A.E., Bachrach, D.G., Wang, Y. and Elmada, A.B. (2011), "Organizational investments in social capital, managerial coaching, and employee work-related performance”, Management Learning, Vol. 42 No. 1, pp. 67-85.

Farrell, A.M. (2010), “Insufficient discriminant validity: a comment on Bove, Pervan, 
Beatty, and Shiu (2009)”, Journal of Business Research, Vol. 63 No. 3, pp. 324-327.

Feldman, D.C. and Lankau, M.J. (2005), "Executive coaching: a review and agenda for future research”, Journal of Management, Vol. 31 No. 6, pp. 829-848.

Fenwick, T. (2008), "Understanding relations of individual-collective learning in work: a review of research”, Management Learning, Vol. 39 No. 3, pp. 227-243.

George, J.M. (1990), "Personality, affect, and behavior in groups”, Journal of Applied Psychology, Vol. 75 No. 2, pp. 107-116.

Good, D.J. (1993), “Managerial coaching as a sales performance moderator”, Journal of Marketing Theory and Practice, pp. 74-83.

Grant, A.M., Passmore, J., Cavanagh, M.J. and Parker, H. (2010), “The state of play in coaching today: a comprehensive review of the field”, Annual Review of Industrial and Organizational Psychology, Vol. 25, pp. 125-168.

Gray, D.E. (2006), "Executive coaching: towards a dynamic alliance of psychotherapy and transformative learning processes”, Management Learning, Vol. 37 No. 4, pp. 475-497.

Hackman, J.R. and Wageman, R. (2005), “A theory of team coaching”, Academy of Management Review, Vol. 30 No. 2, pp. 269-187.

Hagen, M. and Aguilar, M.G. (2012), “The impact of managerial coaching on learning outcomes within the team context: an analysis”, Human Resource Development Quarterly, Vol. 23 No. 3, pp. 363-388.

Hamlin, R.G., Ellinger, A.D. and Beattie, R.S. (2006), "Coaching at the heart of managerial effectiveness: a cross-cultural study of managerial behaviours”, Human Resource Development International, Vol. 9 No. 3, pp. 305-331.

Harzing, A. (1997), "Response rates in international mail surveys: results of a 22-country study”, International Business Review, Vol. 6 No. 6, pp. 641-665.

Heslin, P.A., Vandewalle, D. and Latham, G.P. (2006), “Keen to help? Manager's implicit person theories and their subsequent employee coaching”, Personnel Psychology, Vol. 59 No. 4, pp. 871-902.

Hirst, G., Van Knippenberg, D. and Zhou, J. (2009), “A cross-level perspective on employee creativity: goal orientation, team learning behavior, and individual creativity”, Academy of Management Journal, Vol. 52 No. 2, pp. 280-293.

Hirst, G., Mann, L., Bain, P., Pirola-Merlo, A. and Richver, A. (2004), "Learning to lead: the development and testing of a model of leadership learning”, Leadership Quarterly, Vol. 15 No. 3, pp. 311-327.

Hoegl, M. and Parboteeah, K.P. (2006), “Team reflexivity in innovative projects”, $R \& D$ 
Management, Vol. 36 No. 2, pp. 113-125.

Hooijberg, R. and Lane, N. (2009), "Using multisource feedback coaching effectively in executive education”, Academy of Management Learning and Education, Vol. 8 No. 4, pp. 483-493.

Hui, R.T., Sue-Chan, C. and Wood, R.E. (2013), “The contrasting effects of coaching style on task performance: the mediating roles of subjective task complexity and self-set goal”, Human Resource Development Quarterly, Vol. 24 No. 4, pp. 429-458.

James, L.R. (1982), “Aggregation bias in estimates of perceptual agreement”, Journal of Applied Psychology, Vol. 67 No. 2, pp. 219-29.

James, L.R., Demaree, R.G. and Wolf, G. (1984), "Estimating within-group interrater reliability with and without response bias”, Journal of Applied Psychology, Vol. 69 No. 1, pp. 85-98.

Jordan, S. (2010), "Learning to be surprised: how to foster reflective practice in a high-reliability context”, Management Learning, Vol. 41 No. 4, pp. 391-413.

Kets de Vries, M.F.R. (2005), "Leadership group coaching in action: the Zen of creating high performance teams”, Academy of Management Executive, Vol. 19 No. 1, pp. 61-76.

Kilburg, R.R. (1996), “Toward a conceptual understanding and definition of executive coaching”, Consulting Psychology Journal: Practice and Research, Vol. 48 No. 2, pp. 134-144.

Kim, S., Egan, T.M., Kim, W. and Kim, J. (2013), “The impact of managerial coaching behavior on employee work-related reactions”, Journal of Business and Psychology, Vol. 28 No. 3, pp. 315-330.

Kolb, D.A. (1984), Experiential Learning: Experience as the Source of Learning and Development, Prentice-Hall, Englewood Cliffs, NJ.

LeBreton, J.M. and Senter, J.L. (2008), “Answers to 20 questions about interrater reliability and interrater agreement”, Organizational Research Methods, Vol. 11 No. 4, pp. 815-852.

Lee, L.T. (2008), “The effects of team reflexivity and innovativeness on new product development performance”, Industrial Management \& Data Systems, Vol. 108 No. 4, pp. 548-569.

Liu, C. and Pirola-Merlo, A. (2009), "Disseminating the functions of team coaching regarding research and development team effectiveness: evidence from high-tech industries in Taiwan”, Social Behavior and Personality, Vol. 37 No. 1, pp. 41-58. 
Liu, X. and Batt, R. (2010), “How supervisors influence performance: a multilevel study of coaching and group management in technology-mediated services”, Personnel Psychology, Vol. 63 No. 2, pp. 265-298.

McLean, G.N., Yang, B., Kuo, M.C., Tolbert, A.S. and Larkin, C. (2005), “Development and initial validation of an instrument measuring managerial coaching skill”, Human Resource Development Quarterly, Vol. 16 No. 2, pp. 157-178.

Marks, M.A., Mathieu, J.E. and Zaccaro, S.J. (2001), “A temporally based framework and taxonomy of team processes”, Academy of Management Review, Vol. 26 No. 3, pp. 356-376.

Marsick, V. andWatkins, K. (1990), Informal and Incidental Learning in the Workplace, Routledge, London.

Orth, C.D., Wilkinson, H.E. and Benfari, R.C. (1997), "The manager's role as coach and mentor”, Organizational Dynamics, Vol. 15 No. 4, pp. 66-74.

Passmore, J. and Rehman, H. (2012), “Coaching as a learning methodology: A mixed methods study in driver development using a randomised controlled trial and thematic analysis”, International Coaching Psychology Review, Vol. 7 No. 2, pp. 166-184.

Rousseau, V., Aube, C. and Tremblay, S. (2013), “Team coaching and innovation in work teams: an examination of the motivational and behavioral intervening mechanisms”, Leadership and Organizational Development Journal, Vol. 34 No. 4, pp. 344-264.

Schippers, M., West, M.A. and Dawson, J. (2015), “Team reflexivity and innovation: the moderating role of team context”, Journal of Management, Vol. 41 No. 3, pp. 769-788.

Schippers, M.C., Den Hartog, D.N., Koopman, P.L. and van Knippenberg, D. (2008), "The role of transformational leadership in enhancing team reflexivity", Human Relations, Vol. 61 No. 11, pp. 1593-1616.

Segers, J. and Inceoglu, I. (2012), "Exploring supportive and developmental career management through business strategies and coaching”, Human Resource Management, Vol. 51 No. 1, pp. 99-120.

Shaffer, J.A., DeGeest, D. and Li, A. (2016), "Tackling the problem of construct proliferation: a guide to assessing the discriminant validity of conceptually related construct”, Organizational Research Methods, Vol. 19 No. 1, pp. 80-110.

Somech, A. (2006), "The effects of leadership style and team process on performance and innovation in functionally heterogeneous teams”, Journal of Management, 
Vol. 32 No. 1, pp. 132-157.

Sonesh, S.C., Coultas, C.W., Lacerenza, C.N., Marlow, S.L., Benishek, L.E. and Salas, E. (2015), “The power of coaching: a meta-analytic investigation”, Coaching: An International Journal of Theory, Research and Practice, Vol. 8 No. 2, pp. 73-95.

Stoker, J.I. (2008), "Effects of team tenure and leadership in self-managing teams”, Personnel Review, Vol. 37 No. 5, pp. 564-582.

Theeboom, T., Beersma, B. and van Vianen, A.E.M (2014), "Does coaching work? A meta-analysis on the effects of coaching on individual level outcomes in an organizational context”, Journal of Positive Psychology, Vol. 9 No. 1, pp. 1-18.

van Ginkel, W., Tindale, R.S. and van Knippenberg, D. (2009), “Team reflexivity, development of shared task representations, and the use of distributed information in group decision making”, Group Dynamics: Theory, Research, and Practice, Vol. 13 No. 4, pp. 265-280.

van Mierlo, H., Vermunt, J.K. and Rutte, C.G. (2009), "Composing group-level constructs from individual-level survey data”, Organizational Research Methods, Vol. 12 No. 2, pp. 368-392.

van Woerkom, M. and Croon, M. (2008), “Operationalising critically reflective work behaviour”, Personnel Review, Vol. 37 No. 3, pp. 317-331.

Vashdi, D.R., Bamberger, P.A., Erez, M. and Weiss-Melik, A. (2007), "Briefing-debriefing: using a reflective organizational learning model from the military to enhance the performance of surgical teams”, Human Resource Management, Vol. 46 No. 1, pp. 115-142.

Wageman, R. (2001), "How leaders foster self-managing team effectiveness: design choices versus hand-on coaching”, Organization Science, Vol. 12 No. 5, pp. 559-577.

West, M.A. (1996), "Reflexivity and work group effectiveness: a conceptual integration”, in West, M.A. (Ed.), Handbook of Work Group Psychology, John Wiley and Sons Ltd, Chichester, pp. 555-579.

West,M. A. (2000), "Reflexivity, revolution and innovation in work teams", inBeyerlein,M. M., Johnson, D.A. and Beyerlein, S.T. (Eds), Product Development Teams, Vol. 5, JAI Press, Stamford, CT, pp. 1-29.

Zellmer-Bruhn, M. and Gibson, C. (2006), "Multinational organizational context: implications for team learning and performance", Academy of Management Journal, Vol. 49 No. 3, pp. 501-518. 


\section{Further reading}

Carmeli, A., Sheaffer, Z., Binyamin, G., Reiter-Palmon, R. and Shimoni, T. (2013), "Transformational leadership and creative problem-solving: the mediating role of psychological safety and reflexivity”, Journal of Creative Behavior, Vol. 48 No. 2, pp. 115-135.

\section{Corresponding author}

Makoto Matsuo can be contacted at: mmatsuo@econ.hokudai.ac.jp 